\title{
Periferik Kanında \%100 HbF Bulunan Talasemi İntermedia Olgusu
}

\section{$100 \%$ HbF Found Thalassemia Intermedia Case in Peripheral Blood}

\author{
iD Ayşegül Uğur Kurtoğlu ${ }^{1}$, iD Havva Uçar ${ }^{1}$, iD Esin Eren ${ }^{1}$, iD Vedat Aslan², iD Erdal Kurtoğlu², iD ${ }_{\text {Necat } Y_{1} l m a z}{ }^{1}$ \\ ${ }^{1}$ Sağlık Bilimleri Üniversitesi Antalya Eğitim ve Araştırma Hastanesi Tıbbi Biyokimya Kliniği \\ ${ }^{2}$ Sağlık Bilimleri Üniversitesi Antalya Eğitim ve Araştırma Hastanesi Hematoloji Kliniği
}

\begin{abstract}
$\ddot{\mathbf{O z}}$
$\mathrm{Hb} F$ gestesyonel dönemde sentez edilir ve doğum ile birlikte miktarı giderek azalır. Erişkin bir insanda $\mathrm{Hb} \mathrm{F}<\% 2$ oranında bulunur. HbF’nin oksijene olan afinitesi HbA'ya göre daha fazladır. Bu nedenle $\mathrm{HbF}$ dokulara oksijen taşımak için uygun değildir. Biz bu çalışmamızda; periferik kanında \%100 oranında HbF bulunan yetişkin bir olgudaki hematolojik ve biyokimyasal değişiklikleri inceledik. Anemi semptomları ile hematoloji kliniğinde takip edilen 66 yaşındaki erkek hastanın tam kan sayımında; RBC: 3.1 1012/L, Hb: 8.3 g/dL, Hct: 27.6 \%, MCV: 90.1 f/L, PLT: 793000 103/mm3 idi. Serum ferritin: 1094 ng/mL, total bilirubin: $4 \mathrm{mg} / \mathrm{dL}$, direkt bilirubin: $0.68 \mathrm{mg} / \mathrm{dL}$ olarak tespit edildi. Hastanın hemoglobin varyant analizinde $\% 100$ oranında HbF olduğu belirlendi. Hastada HbA'nın hiç olmadığ tespit edildi. Hasta talasemi intermedia olarak değerlendirildi.
\end{abstract}

Anahtar Kelimeler: HbF, Talasemi İntermedia, Beta globin gen delesyonu

\begin{abstract}
$\mathrm{Hb} \mathrm{F}$ is synthesized in the gestational period and the amount decreases gradually with

delivery. In an adult person, $\mathrm{Hb} \mathrm{F}$ is $<2 \%$. The affinity of $\mathrm{HbF}$ to oxygen is higher than $\mathrm{HbA}$. HbF is therefore not suitable for transporting oxygen to tissues. In this study; We investigated the hematological and biochemical changes in an adult patient with $100 \% \mathrm{HbF}$ in peripheral blood. Complete blood count of a 66-year-old male patient followed up in hematology clinic with symptoms of anemia; RBC: 3.1 1012 / L, Hb: 8.3 g / dL, Hct: $27.6 \%$, MCV: 90.1 f/ L, PLT: 793000103 / mm3. Serum ferritin: $1094 \mathrm{ng} / \mathrm{mL}$, total bilirubin: $4 \mathrm{mg} / \mathrm{dL}$, direct bilirubin: $0.68 \mathrm{mg} / \mathrm{dL}$. The hemoglobin variant analysis revealed 100\% $\mathrm{HbF}$. The patient had no HbA. The patient was evaluated as thalassemia intermedia.
\end{abstract}

Keywords: $\mathrm{HbF}$, Thalassemia Intermedia, Beta globin gene deletion

Amaç: $\operatorname{HbF}\left(\alpha_{2} \gamma_{2}\right)$ molekülünün yapısında bulunan $\gamma$ zincirinde 136 amino asit (aa) olarak fizyolojik pH'da yüksüz olan alanin ve glisin bulunmaktadır, $\mathrm{Bu}$ aa farklılıklarından dolayı 2,3-bisfosfogliserat $\mathrm{HbF}$ molekülüne zayıf bağlanır ve $\mathrm{HbF}$ molekülünün oksijene olan afinitesi $\operatorname{artar}(1)$. HbF'in \%50 doygunluğa ulaştığ $\mathrm{pO}_{2}$ değeri yaklaşık olarak 19 mmHg iken, HbA'nın ise 27 mmHg'dır. Bu özelliği nedeni ile HbF oksijenin anneden fötüse taşınmasını kolaylaştırdığ için intrauterin dönemin en önemli hemoglobinidir (2). Gestasyonel dönemde \%6070 oranında bulunan $\mathrm{HbF}$ düzeyleri doğum ile birlikte giderek azalır. Erişkin bir insanda HbF miktarı <\%2'dır (3). Biz bu çalışmamızda; periferik kanında \%100 oranında $\mathrm{HbF}$ bulunan yetişkin bir olgudaki hematolojik ve biyokimyasal değişiklikleri inceledik.

Olgu: Anemi semptomları ile hematoloji kliniğinde takip edilen 66 yaşındaki erkek hastanın anamnezinde; 56 yaşında geçirilmiş bir pulmoner enfeksiyon sonrasında 2 ünite ve 65 yaşında 1 ünite kan transfüzyonu olmak üzere sadece 2 defa transfüzyon ihtiyacı olduğu öğrenildi. Fizik muayenesinde hafif ikterik görünümlü, fenotipik olarak hemoglobinopati şüphesini düşündüren maksillar kemiklerde belirginleşme dışında başka bir bulgu yoktu. Laboratuvar tetkiklerinde tam kan sayımında; RBC: 3.1 10 ${ }^{12} / \mathrm{L}, \mathrm{Hb}: 8.3 \mathrm{~g} / \mathrm{dL}$, Hct: $27.6 \%$,
MCV: 90.1 f/L, PLT: 793000 103/ $\mathrm{mm}^{3}$ idi. Serum ferritin: $1094 \mathrm{ng} /$ $\mathrm{mL}$, total bilirubin: $4 \mathrm{mg} / \mathrm{dL}$, direkt bilirubin: $0.68 \mathrm{mg} / \mathrm{dL}$ olarak tespit edildi. Hastanın hemoglobin varyant analizi Biorad Variant II HPLC cihazında ölçüldü. Hemoglobin kromotogramında $\mathrm{HbF}$ \%109.2, $\mathrm{HbA} 2 \% 1.6$ ve HbA0 \%0 olduğu gözlendi (Figure 1). Beta globin DNA dizi analizinde, HBB c.25_26delAA mutasyonu homozigot olarak tespit edildi. Hasta klinik olarak talasemi intermedia olgusu olarak değerlendirildi.

Yazışma Adresi: Ayşegül Uğur Kurtoğlu, Varlık Mah. Antalya Eğitim ve Araştırma Hastanesi, Biyokimya Klinigi, Antalya/TURKEY

E-Posta: ugurkurtoglu@yahoo.com

Alınma Tarihi: 26.09.2018 / Kabul Tarihi: 22.03.2019 / Yayımlanma Tarihi: 15.06.2021 
Figure 1

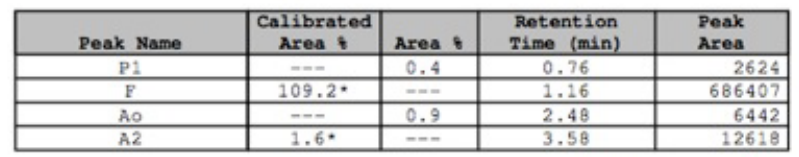

Total Area: 708,091*

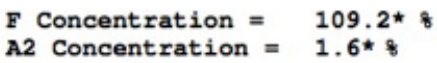

-Values outside of expected ranges

Analysis comments:

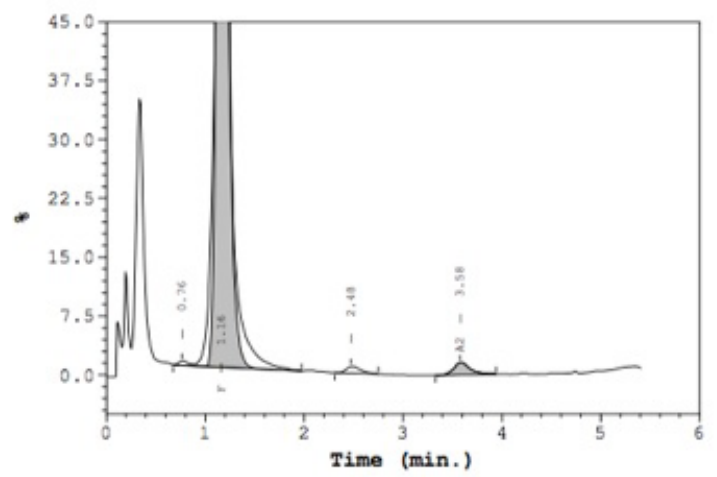

Sonuç: Globuler protein yapısında olan ve erişkin dönemin major hemoglobin olan $\mathrm{HbA}$ iki alfa ve iki beta globin zinciri içerir. $\mathrm{Bu}$ globin zincirlerindeki mutasyonlar sonucu hemoglobinopatiler olarak adlandırılan ve ülkemizde de sık olarak görülen hastalık grubu ortaya çıkar (4). Bu hastalık grubundan biri olan; yüksek $\mathrm{HbF}$ düzeyleri Delta-beta talasemi ve Herediter Persistant HbF (HPPF) olgularında görülebilir. Delta- beta talasemi genellikle delta ve beta globin genindeki delesyonlar veya promoter bölgesindeki substitisyonlar sonucu oluşur ve $\mathrm{HbA} / \mathrm{A}_{2}$ düzeylerinde azalma ile sonuçlanır (5). Biz olgumuzda beta gen bölgesinde delesyon olduğunu tespit ettik. $\mathrm{Bu}$ delesyona bağlı olarak periferk kanında HbA bulunmayan olgumuzda, $\mathrm{HbF}$ yaklaşı olarak \%100 oranında bulunmaktaydı. Literatürde $\mathrm{HbF}$ düzeyleri $\% 100$ oranlarinda bulunan olgularla ilgili az sayıda da olsa birkaç yayın bulunmaktadır (6). Literatürde belirtilen bu yayınlar genellikle çoçukluk yaş grubuna ait olan bilgilerdir (7). Khunger ve arkadaşları 10 yaşındaki hastalarını hipokromik mikrositer anemisi bulunan talasemi intermedia olgusu olarak değerlendirmişler (8). Bizim olgumuz 66 yaşında ve hayatı boyunca sadece 2 defa kan transfüzyonuna gereksinim gösteren anemisi dışında önemli bir sağlık problemi yoktu.

Gestasyonel dönemin major hemoglobini olan $\mathrm{HbF}$, erişkin dönemde baskın olarak bulunduğu zaman talasemi intermedia ile uyumlu semptomlara neden olur. Bu çalışmamızın \%100 HbF düzeyi bulunan hastalarda; ileri yaşlara kadar önemli sağlık problemleri olmaksızın yaşam beklentilerinin olabileceğini gösterdiği için literature katkı sağlayacağını düşünmekteyiz.

\section{Kaynaklar}

1. Akinsheye I, Alsultan A, Solovieff N, Ngo D, Baldwin CT, Sebastiani P, Chui DH, Steinberg MH. Fetal hemoglobin in sickle cell anemia. Blood. 2011;118(1):1927.

2. Sokolova A, Mararenko A, Rozin A, Podrumar A, Gotlieb V. Hereditary persistence of hemoglobin $\mathrm{F}$ is protective against red cell sickling. A case report and brief review. Hematol Oncol Stem Cell Ther doi: 10.1016/j.hemonc.2017.09.003.

3. Zivot A, Lipton JM, Narla A, Blanc L. Erythropoiesis: insights into pathophysiology and treatments in 2017. Mol Med. 2018;24(1):11.

4. Aydinok Y. Thalassemia. Hematology. 2012;17(1):28-31.

5. Kumar BV, Choccalingam C, Samuel P. Incidental Identification of Possible DeltaBeta Thalassemia Trait in a Family: A Rare Cause of Elevated Hb F. J Clin Diagn

Genel Tip Derg 2021;31(2)180-181

181
Res. 2016;10(3):1-2.

6. Mansoori H, Asad S, Rashid A, Karim F. Delta beta thalassemia: a rare hemoglobin variant. Blood Res. 2016;51(3):213-14.

7. Verma S, Bhargava M, Mittal S, Gupta R. Homozygous delta-beta Thalassemia in a Child: a Rare Cause of Elevated Fetal Hemoglobin. Iran J Ped Hematol Oncol. 2013;3(1):222-7.

8. Khunger JM, Gupta M, Singh R, Kapoor R, Pandey HR. Haematological characterisation and molecular basis of asian Indian inversion deletions deltaBeta thalassemia: a case report. J Clin Diagn Res. 2014;8(9):1-2. 